\title{
PILLARS OF COMPETITIVENESS AS FDI DETERMINANTS IN HOST COUNTRIES: A REVIEW OF THE PANEL DATA EMPIRICAL STUDIES
}

\author{
Biljana Stankov* \\ Novi Sad School of Business, Novi Sad, Republic of Serbia \\ Jelena Damnjanović \\ Novi Sad School of Business, Novi Sad, Republic of Serbia \\ Milijana Roganović \\ Novi Sad School of Business, Novi Sad, Republic of Serbia
}

\begin{abstract}
Scientific literature abounds in empirical studies in which, using various econometric methods, the determinants of foreign direct investments (FDI) are researched. On the other hand, there are a modest number of studies dealing with pillars of competitiveness or other elements of competitiveness as key determinants of FDI inflows in host countries. The aim of the paper is to point out to the importance of research of these issues by the review of mentioned studies, as well as highlight the advantages of econometric methodology in the field of panel data regression models which are used in these researches, and to come to a conclusion which pillars of competitiveness most often appear as determinants of FDI inflows. Through a detailed overview of selected research studies that, using the same methodology, deal with the researched problem, the authors wanted to set a safe basis for future researches in that area and thereby contribute to the enrichment of scientific literature.
\end{abstract}

Key words: foreign direct investments, host country, panel data analysis, FDI determinants

JEL Classification: F21, C23, C33

\footnotetext{
*bilja.1.stankov@gmail.com
} 


\section{STUBOVI KONKURENTNOSTI KAO DETERMINANTE PRILIVA STRANIH DIREKTNIH INVESTICIJA U ZEMLJAMA DOMAĆINIMA: PREGLED EMPIRIJSKIH STUDIJA U KOJIMA JE PRIMENJENA PANEL ANALIZA}

Sažetak: Naučna literatura je veoma bogata emprijskim studijama u kojima se, primenom različitih ekonometrijskih metoda, istražuju determinante stranih direktnih investicija (SDI). S druge strane, postoji skroman broj studija koje se bave stubovima ili drugim elementima konkurentnosti kao ključnim determinantama priliva stranih direktnih investicija u zemljama domaćinima. Cilj rada jeste da se pregledom pomenutih studija ukaže na značaj istraživanja ove problematike, istaknu prednosti ekonometrijske metodologije u oblasti analize regresionih panel modela primenjenih u ovim istraživanjima, $i$ dođe do zaključka koji se stubovi konkurentnosti najčešće pojavljuju kao determinante priliva stranih direktnih investicija. Iscrpnim pregledom odabranih istraživačkih studija koje se, primenjujući istu metodologiju, bave istraživanim problemom, autori rada su želeli da postave sigurnu osnovu za buduća istraživanja iz date oblasti i time pruže doprinos obogaćivanju naučne literature.

Ključne reči: strane direktne investicije, zemlja domaćin, panel analiza, determinante stranih direktnih investicija

\section{INTRODUCTION}

In the scientific literature competitiveness has been claimed to be of one of the determinants of FDI inflows, since it has been associated with high standard of living, cost reduction, quality standards, improvement of business processes, efficiency, and so on. Studies regarding the correlation between competitiveness and FDI inflows are scarce in the literature mainly due to the lack of a universally accepted definition of competitiveness (Criste, Mosneanu and Glod, 2008). In the emerging and developing countries national competitiveness has certainly been a very important determinant of FDI inflows, but it has also been a significant factor in developed countries. If a country is more competitive in comparison to the others, especially the ones in its immediate surrounding or the ones which are in many ways similar to it, its investment environment becomes more attractive for foreign investors. In such circumstances, FDI inflows are expected to intensify and thus 
stimulate economic growth and development. Competitiveness affects the achieved level of productivity in the country, and directly determines the level of social well-being. On the other hand, FDI is often seen in scientific literature as a source of competitiveness, since it secures transfer of technology and knowledge from home to host countries through capital flows.

Improving competitiveness should be an integral part of national development strategy of all countries, especially developing ones. Depending on the stage of economic development, a change has been observed in the significance and contribution of individual pillars of competitiveness in the overall competitive result and the positioning of countries in the Global Competitiveness Report $(G C R)$ which is developed by the World Economic Forum $(W E F)$. For example, for the competitiveness of the emerging and developing European countries, whose economies are in the second stage of development or in the transition period from the second to the third stage, key efficiency enhancers are: higher education and training, goods market efficiency, labour market efficiency, financial market development, technological readiness and market size, because these are the pillars of competitiveness that need to be improved in this stage of development. However, unless it is supported by an efficient institutional sector, developed infrastructure and a stable macroeconomic environment, which are the basic elements of development, it is not a rare case that development cannot be continued, or it continues slowly and with difficulties. When higher levels of economic development are achieved, some innovation factors like business sophistication and the importance of innovation, come to focus, and especially in developed countries, they stand out as key determinants of FDI inflows. In many empirical studies, certain indicators of competitiveness, as well as the pillars of competitiveness, are independent variables.

By analysing various research papers, it has been concluded that a large number of authors have studied determinants of FDI inflows, both in developing and developed countries, and that very few of them have researched pillars of competitiveness as factors which significantly influence the decision-making process of foreign investors and reaching a final decision on the choice of location for the investment. Because of the aforementioned reasons, the authors of this study are determined to show the results of the selected empirical studies, considering the length of the research period, the size and structure of the research sample, the way of expressing an independent variable, the type of regression model used in a panel data analysis, and to analyse the impact of competitiveness SCHOOL OF BUSINESS, 2/2018, 98-116 
101 | PILLARS OF COMPETITIVENESS AS FDI DETERMINANTS IN HOST COUNTRIES: A REVIEW OF THE PANEL DATA EMPIRICAL STUDIES

pillars, as independent variables, on FDI inflows in host countries, as dependent variables.

\section{PANEL DATA ANALYSIS}

In econometric research, the popularity of the methodology which prescribes the use of panel data analysis is gradually growing. By using a panel data set, researchers can significantly increase the sample size and thus perform an analysis that cannot be performed using cross-sectional data and time series data. The panel data are a combination of time series data and cross-sectional data as they provide both time and space dimensions (Gujarati and Porter, 2009). These data represent a special form of combined data in which the same cross-sectional unit (e.g. state, company, etc.) is analysed over time (Gujarati, 2004). The panel data set contains data of a large number of the same units of observation at given moments or periods of time, and each observation at the same time contains spatial and temporal dimension. This enables all relevant information from the sample to be used in the evaluation of regression parameters (Matyas and Sevestre, 1996). Since panel data sets are by their nature disaggregated by units of observation, and since each panel observation carries information about the structure and dynamics of the observed phenomenon, panel data sets are becoming more and more popular in quantifying economic relations (Dragutinović-Mitrović, 2002). Baltagi (2005) believes that panel data provide a greater possibility of identifying and measuring effects that cannot be identified using only cross-sectional data of multiple units of observation or time series data of a single unit of observation. In addition, by using the econometric methodology and analysing panel data regression, authors of empirical studies on competitiveness and determinants of FDI inflows can obtain maximum information from a limited number of degrees of freedom in the sample. Dragutinović-Mitrović (2002) points out that in this way, a higher efficiency of econometric estimations of parameters in model with less restrictive assumptions is provided.

In a limited number of research studies that analyse determinants of FDI inflows, independent variables are pillars of competitiveness, expressed as elements of the Global Competitiveness Index $(G C I)$ and defined by the WEF. One of the few authors studying variables of competitiveness is Anastassopoulos (2007). While studying the correlation between competitiveness and FDI inflows in host countries, the author uses factors that represent competitiveness according to IMD World Competitiveness Centre. The research studies available to the authors of this study are those of Popovici and Calin (2015), Ungureanu and Burcea (2014), Amar 
and Hamdi (2012) and Stankov (2017). These studies use data on competitiveness published in the GCR. Also, only Popovici and Calin (2015) and Stankov (2017) use the pillars of competitiveness as the independent variables in their research and examine the impact of increase in competitiveness on FDI inflows in the countries of the CEE region (Popovici and Calin, 2015), that is to say, in the emerging and developing Europe (Stankov, 2017). Stankov, Markov and Marjanski Lazic (2014) state that by analysing and using the results from GCR, the country's ability to see competitive advantages and disadvantages increases, its global competitive position improves, and better conditions for stimulating economic growth and development are created. Consequently, the country will be able to find a way out of the global financial crisis as soon as possible and create a stable path to economic recovery. Nevertheless, regardless of the aforementioned nonconformity, the variables that determine competitiveness present significant factors that may attract FDI, according to many.

\section{EMPIRICAL STUDIES ON THE IMPACT OF PILLARS OF COMPETITIVENESS ON FDI INFLOWS IN HOST COUNTRIES}

Within this chapter, the authors of the paper analyse the results of the presented empirical studies (Table 1). The paper examines only the studies of those authors who use panel data regression model and explore the impact of independent variables (pillars of competitiveness) on FDI inflows in host countries, as a dependent variable, and their correlation. Independent research variables are the pillars of competitiveness, or certain elements of competitiveness as their constituent components, namely: Institutions, Infrastructure, Macroeconomic environment, Health and primary education, Higher education and training, Goods market efficiency, Labor market efficiency, Financial market development, Technological readiness, Market size, Business sophistication and Innovation.

Anastassopoulos (2007) investigated the correlation between international competitiveness and FDI in the selected EU countries. The sample covered 15 countries that were analysed in the period from 2003 to 2006. Using panel data analysis and the OLS regression model (Ordinary Last Squares), the author found that many independent variables were statistically significant. Positive impact on FDI was identified in the case of energy infrastructure, skilled workforce, labour productivity and market size, while the institutional variables, that is, public debt and tax burden on economic entities, showed a negative SCHOOL OF BUSINESS, 2/2018, 98-116 
103 | PILLARS OF COMPETITIVENESS AS FDI DETERMINANTS IN HOST COUNTRIES: A REVIEW OF THE PANEL DATA EMPIRICAL STUDIES

impact. In these EU countries, a large market, quality infrastructure, qualified and productive labour force can stimulate FDI inflows, but only if the efficiency of the institutional sector is increased, macroeconomic balance is established through the reduction of public debt, and the overall tax burden on business entities is reduced by lowering the corporate income tax rate.

Anyanwu (2011) investigated the impact of certain determinants on FDI inflows in 50 African countries over the period from 1980 to 2007. Using the panel data analysis, OLS and GLM regression model (Generalized Linear Model), the author found that the impact of infrastructure and inflation, as indicators of macroeconomic stability, was insignificant for FDI. A positive and statistically significant impact was found in the case of administration costs, as an institutional variable, and trade openness, while financial market development as an independent variable showed negative and statistically significant impact on FDI inflows. Many authors who examined the determinants of FDI inflows in African countries argued that "Africa is different", since the obtained results showed that the usual, expected effects of traditional variables were lacking in this case. Trade openness and administration costs stimulated FDI inflows in the analysed African countries in that period (which is not in line with expectations), while with the increase of financial market development, the attractiveness for FDI diminished.

Bevan and Estrin (2000) examined FDI flows from 18 market economies to 11 transition ones in order to identify key factors affecting FDI inflows in the European transition economies. Using panel dataset and random effects regression model they concluded that a sufficiently large market, stable government budget balance, high foreign exchange reserves and developed private sector could have a positive impact, while high labour costs a negative impact on FDI flows in the countries analysed from 1994 to 1998 .

Bevan and Estrin (2004) are also authors of another empirical study, which differs from the previous one only by the length of the period of time over which the research was conducted (1994-2000). The conclusion of the study determined market size and labour costs as statistically significant variables for FDI inflows. The research confirmed the positive impact of a sufficiently large market and the negative impact of high labour costs on FDI inflows in the European transition economies.

Cheng and Kwan (2000) attempted to uncover the factors that had the greatest impact on location choice of FDI in China, and for this reason they analysed 29 Chinese regions over a ten-year period (1985-1995). By 
using the panel data analysis and the GMM model (Generalized Method of Moments) they concluded that the quality of the infrastructure and the market size had a positive and statistically significant effect on FDI inflows, while high labour costs could discourage foreign investors, since this independent variable exerted negative, statistically significant impact. The same authors found that during the given period, the quality of labour force in China did not significantly affect the decisions of foreign investors.

Dhakal, Mixon and Upadhyaya (2007) examined the impact of certain determinants on FDI flows in the European transition economies between 1995 and 2004. The results of the panel data analysis and the fixed effects regression model showed that there was a statistically significant impact of government regulation, inflation rate and trade openness, as independent variables, while market size was an insignificant variable. The authors concluded that, in the given period, in the developing European countries, market openness could have positive effect, while the rate of inflation and the ineffectiveness of government regulation negative effect on FDI inflows. 


\begin{tabular}{|c|c|c|c|c|c|c|c|c|c|c|c|c|c|c|c|c|}
\hline \multirow[b]{2}{*}{ Author/Authors } & \multirow[b]{2}{*}{$\begin{array}{c}\text { Research } \\
\text { period }\end{array}$} & \multirow[b]{2}{*}{$\begin{array}{c}\text { Size and } \\
\text { structure of } \\
\text { the research } \\
\text { sample }\end{array}$} & \multirow[b]{2}{*}{$\begin{array}{c}\text { Research } \\
\text { method }\end{array}$} & \multirow[b]{2}{*}{ 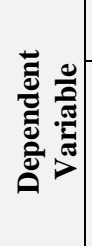 } & \multicolumn{12}{|c|}{ INDEPENDENT VARIABLES } \\
\hline & & & & & \begin{tabular}{l}
\multirow{\vdots}{\vdots}{} \\
$\vdots$ \\
$\vdots$
\end{tabular} & $\underset{⿱ 亠 乂}{\mathbb{2}}$ & $\begin{array}{l}0 \\
0 \\
\frac{8}{2}\end{array}$ & 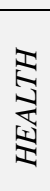 & 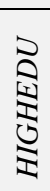 & $\begin{array}{l}\tilde{0} \\
0 \\
0\end{array}$ & $\begin{array}{l}5 \\
5 \\
0 \\
5 \\
5\end{array}$ & $\sum_{\substack{0 \\
\vdots}}^{\substack{1 \\
\vdots}}$ & 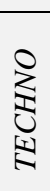 & $\frac{\sqrt[1]{2}}{2}$ & 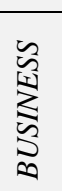 & $\begin{array}{l}\grave{3} \\
\vdots \\
\vdots\end{array}$ \\
\hline $\begin{array}{l}\text { Anastassopoulos, } \\
\text { G. (2007) }\end{array}$ & $2003-2006$ & $\begin{array}{l}\text { (15); EU } \\
\text { countries }\end{array}$ & $\begin{array}{l}\text { Panel data } \\
\text { analysis } \\
\text { (OLS } \\
\text { regression) }\end{array}$ & & $\overline{(\mathbf{S})}$ & $\begin{array}{c}+ \\
(\mathbf{S})\end{array}$ & $\begin{array}{l}- \\
\text { (S) }\end{array}$ & & $\begin{array}{l}+ \\
\text { (S) }\end{array}$ & $\dot{-}$ & $\begin{array}{l}+ \\
\text { (S) }\end{array}$ & & & $\begin{array}{c}+ \\
(\mathbf{S})\end{array}$ & & \\
\hline $\begin{array}{l}\text { Anyanwu, J., C. } \\
\text { (2011) }\end{array}$ & $1980-2007$ & $\begin{array}{l}\text { (50); African } \\
\text { countries } \\
\text { (diferent } \\
\text { number per } \\
\text { year) }\end{array}$ & $\begin{array}{l}\text { Panel data } \\
\text { analysis } \\
\text { (OLS i } \\
\text { GLM } \\
\text { regression) }\end{array}$ & & $\begin{array}{c}+ \\
(\mathbf{S})\end{array}$ & NS & NS & & & & & $\dot{-}$ & & $\begin{array}{c}+ \\
(\mathbf{S})\end{array}$ & & \\
\hline $\begin{array}{l}\text { Bevan, A., A., } \\
\text { and Estrin, S. } \\
(2004)\end{array}$ & 1994. - 2000. & $\begin{array}{c}(18+11) ; \\
\text { Home } \\
\text { countries and } \\
\text { Host } \\
\text { countries } \\
\end{array}$ & $\begin{array}{c}\text { Panel data } \\
\text { analysis } \\
\text { (Random } \\
\text { Effects) }\end{array}$ & & & & & & & & $\begin{array}{l}- \\
\text { (S) }\end{array}$ & & & $\begin{array}{c}+ \\
(\mathbf{S})\end{array}$ & & \\
\hline $\begin{array}{l}\text { Bevan, A., and } \\
\text { Estrin, S. (2000) }\end{array}$ & 1994. - 1998. & $\begin{array}{c}(18+11) ; \\
\text { Home } \\
\text { countries and } \\
\text { Host } \\
\text { countries } \\
\end{array}$ & $\begin{array}{l}\text { Panel data } \\
\text { analysis } \\
\text { (Random } \\
\text { Effects) }\end{array}$ & & $\begin{array}{c}+ \\
(\mathbf{S})\end{array}$ & & $\begin{array}{l}+ \\
\text { (S) }\end{array}$ & & & & $\begin{array}{c}- \\
\text { (S) }\end{array}$ & & & $\begin{array}{c}+ \\
(\mathbf{S})\end{array}$ & & \\
\hline $\begin{array}{l}\text { Cheng, L., and } \\
\text { Kwan, Y. (2000) }\end{array}$ & 1985. - 1995. & $\begin{array}{l}(29) ; \\
\text { Regions in } \\
\text { China }\end{array}$ & $\begin{array}{l}\text { Panel data } \\
\text { analysis } \\
\text { (GMM } \\
\text { regression) }\end{array}$ & & & $\begin{array}{c}+ \\
(\mathbf{S})\end{array}$ & & & NS & & $\begin{array}{c}- \\
\text { (S) }\end{array}$ & & & $\begin{array}{c}+ \\
(\mathbf{S})\end{array}$ & & \\
\hline $\begin{array}{l}\text { Dhakal, D., } \\
\text { Mixon, F., and } \\
\text { Upadhyaya, K. } \\
\text { (2007) }\end{array}$ & 1995. - 2004. & $\begin{array}{c}(8) ; \\
\text { Europena } \\
\text { countries in } \\
\text { transition }\end{array}$ & $\begin{array}{l}\text { Panel data } \\
\text { analysis } \\
\text { (Fixed } \\
\text { Effects) }\end{array}$ & & (S) & & (') & & & & & & & $\begin{array}{c}\text { NS/ } \\
+ \\
(\mathbf{S})\end{array}$ & & \\
\hline
\end{tabular}




\begin{tabular}{|c|c|c|c|c|c|c|c|c|c|c|c|c|c|c|c|c|}
\hline \multirow[b]{2}{*}{ Author/Authors } & \multirow[b]{2}{*}{$\begin{array}{l}\text { Research } \\
\text { period }\end{array}$} & \multirow{2}{*}{$\begin{array}{c}\text { Size and } \\
\text { structure of } \\
\text { the research } \\
\text { sample }\end{array}$} & \multirow[b]{2}{*}{$\begin{array}{l}\text { Research } \\
\text { method }\end{array}$} & \multirow{2}{*}{ 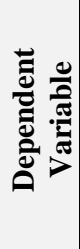 } & \multicolumn{12}{|c|}{ INDEPENDENT VARIABLES } \\
\hline & & & & & 太্ & $\frac{\substack{\frac{1}{x} \\
\vdots}}{\vdots}$ & 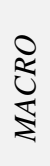 & 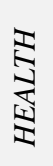 & 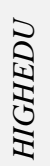 & 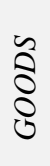 & $\begin{array}{l}5 \\
\vdots \\
0 \\
\vdots \\
\vdots \\
1\end{array}$ & 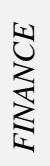 & 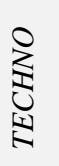 & $\frac{\sqrt[T]{2}}{2}$ & 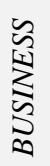 & $\sum_{\vdots}^{\frac{\pi}{2}}$ \\
\hline $\begin{array}{l}\text { Holland, D., and } \\
\text { Pain, N. (1998) }\end{array}$ & 1992. - 1996. & $\begin{array}{l}\text { (8); Eastern } \\
\text { European } \\
\text { countries }\end{array}$ & $\begin{array}{l}\text { Panel data } \\
\text { analysis } \\
\text { (Fixed } \\
\text { Effects) } \\
\end{array}$ & & & & & & & & $\begin{array}{c}- \\
(\mathbf{S})\end{array}$ & & & & & \\
\hline $\begin{array}{l}\text { Kinoshita, Y., } \\
\text { and Campos, N., } \\
\text { F. (2002) }\end{array}$ & 1990. - 1998. & $\begin{array}{c}(25) ; \\
\text { Countries in } \\
\text { transition }\end{array}$ & $\begin{array}{l}\text { Panel data } \\
\text { analysis } \\
\text { (Fixed } \\
\text { effects) }\end{array}$ & & $\begin{array}{c}+ \\
(\mathbf{S})\end{array}$ & $\begin{array}{c}+ \\
(\mathbf{S})\end{array}$ & NS & & $\begin{array}{c}+ \\
\stackrel{+}{(S)}\end{array}$ & $\stackrel{+}{+} \underset{(\mathbf{S})}{ }$ & NS & & & $\begin{array}{c}+ \\
(\mathbf{S})\end{array}$ & & \\
\hline $\begin{array}{l}\text { Kudaisi, B., V. } \\
\text { (2014) }\end{array}$ & 1980. - 2012. & $\begin{array}{l}\text { (16); North } \\
\text { African } \\
\text { countries }\end{array}$ & $\begin{array}{l}\text { Panel data } \\
\text { analysis } \\
\text { (Fixed } \\
\text { Effects) }\end{array}$ & & & $\begin{array}{c}+ \\
(\mathbf{S})\end{array}$ & $\dot{\bar{S}}$ & & & & & & & $\begin{array}{l}- \\
\text { (S)/ } \\
\text { NS }\end{array}$ & & \\
\hline $\begin{array}{l}\text { Mottaleb, K., A. } \\
(2007)\end{array}$ & 2003. - 2005. & $\begin{array}{c}(60) ; \\
\text { Countries of } \\
\text { Asia, Africa } \\
\text { and Latin } \\
\text { America }\end{array}$ & $\begin{array}{l}\text { Panel data } \\
\text { analysis } \\
\text { (Random } \\
\text { Effects) }\end{array}$ & & NS & NS & & & & NS & & & $\begin{array}{c}+ \\
(\mathbf{S})\end{array}$ & $\begin{array}{c}+ \\
(\mathbf{S})\end{array}$ & & \\
\hline $\begin{array}{l}\text { Nishat, M., and } \\
\text { Aqeel, A. (2004) }\end{array}$ & 1961. - 2002. & (1); Pakistan & $\begin{array}{l}\text { Panel data } \\
\text { analysis } \\
\text { (Error } \\
\text { Correction) }\end{array}$ & & & & & & & $\dot{-}$ & NS & $\begin{array}{c}+ \\
\text { (S) }\end{array}$ & & $\begin{array}{c}+ \\
(\mathbf{S})\end{array}$ & & \\
\hline
\end{tabular}




\begin{tabular}{|c|c|c|c|c|c|c|c|c|c|c|c|c|c|c|c|c|}
\hline \multirow[b]{2}{*}{ Author/Authors } & \multirow[b]{2}{*}{$\begin{array}{c}\text { Research } \\
\text { period }\end{array}$} & \multirow[b]{2}{*}{$\begin{array}{c}\text { Size and } \\
\text { structure of } \\
\text { the research } \\
\text { sample }\end{array}$} & \multirow[b]{2}{*}{$\begin{array}{l}\text { Research } \\
\text { method }\end{array}$} & \multirow[b]{2}{*}{ 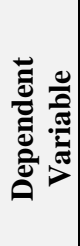 } & \multicolumn{12}{|c|}{ INDEPENDENT VARIABLES } \\
\hline & & & & & $\underset{\vdots}{\vdots}$ & $\begin{array}{l}\mathbb{2} \\
\vdots \\
\vdots\end{array}$ & 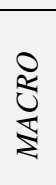 & 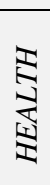 & 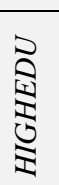 & 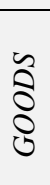 & $\begin{array}{l}5 \\
5 \\
0 \\
0 \\
5\end{array}$ & 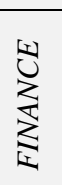 & $\sum_{\substack{\vdots \\
N}}^{0}$ & $\frac{\sqrt{y}}{2}$ & 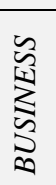 & $\begin{array}{l}\longleftarrow \\
\vdots \\
\vdots\end{array}$ \\
\hline $\begin{array}{l}\text { Popovici, O., C., } \\
\text { and Calin, A., C. } \\
\text { (2015) }\end{array}$ & 2013. & $\begin{array}{c}(10) ; \mathrm{CEE} \\
\text { countries and } \\
\text { EU members }\end{array}$ & $\begin{array}{c}\text { Panel data } \\
\text { analysis } \\
\text { (Correlatio } \\
\text { n) }\end{array}$ & & $\begin{array}{l}+ \\
\text { (S) }\end{array}$ & $\begin{array}{l}+ \\
\text { (S) }\end{array}$ & NS & & NS & $\stackrel{+}{\stackrel{+}{(S)}}$ & $\begin{array}{l}+ \\
\text { (S) }\end{array}$ & NS & $\begin{array}{l}+ \\
(\mathbf{S})\end{array}$ & & $\begin{array}{c}+ \\
(\mathbf{S})\end{array}$ & $\begin{array}{l}+ \\
(\mathbf{S})\end{array}$ \\
\hline $\begin{array}{l}\text { Ranjan, V., and } \\
\text { Agarwal, G. } \\
\text { (2011) }\end{array}$ & 1975. - 2009. & $\begin{array}{l}\text { (4); BRICS } \\
\text { countries }\end{array}$ & $\begin{array}{l}\text { Panel data } \\
\text { analysis } \\
\text { (Random } \\
\text { Effects) }\end{array}$ & & & $\begin{array}{c}+ \\
\text { (S) }\end{array}$ & NS & & NS & & (S) & & & $\begin{array}{c}+ \\
(\mathbf{S})\end{array}$ & & \\
\hline $\begin{array}{l}\text { Schneider, F., and } \\
\text { Frey, B. (1985) }\end{array}$ & $\begin{array}{c}\text { 1976., 1979. i } \\
1980 .\end{array}$ & $\begin{array}{l}\text { (54); Non- } \\
\text { European } \\
\text { developing } \\
\text { countries }\end{array}$ & $\begin{array}{l}\text { Panel data } \\
\text { analysis } \\
\text { (Multiple } \\
\text { Regression) }\end{array}$ & & $\begin{array}{l}+ \\
\text { (S) }\end{array}$ & & $\begin{array}{c}- \\
(\mathbf{S})\end{array}$ & & $\begin{array}{c}+ \\
(\mathbf{S})\end{array}$ & & (S) & & & $\begin{array}{c}+ \\
(\mathbf{S})\end{array}$ & & \\
\hline Stankov (2017) & $2008-2017$ & $\begin{array}{c}\text { Emerging } \\
\text { and } \\
\text { developing } \\
\text { European } \\
\text { countries }\end{array}$ & $\begin{array}{l}\text { Panel data } \\
\text { analysis } \\
\text { (Fixed } \\
\text { Effects) }\end{array}$ & & & & & & & & & & & & & \\
\hline $\begin{array}{l}\text { Vijayakumar, N., } \\
\text { Sridharan, P., and } \\
\text { Sekhara Rao, K., } \\
\text { C. (2010) }\end{array}$ & 1975. - 2007. & $\begin{array}{l}\text { (5); BRICS } \\
\text { countries }\end{array}$ & $\begin{array}{c}\text { Panel data } \\
\text { analysis } \\
\text { (Random } \\
\text { Effects) }\end{array}$ & & & $\begin{array}{c}+ \\
(\mathbf{S})\end{array}$ & NS & & & & $\begin{array}{l}- \\
\text { (S) }\end{array}$ & & & $\begin{array}{l}+ \\
(\mathbf{S}) / \\
\text { NS }\end{array}$ & & \\
\hline
\end{tabular}

Note. Selected by the authors. 
Interpretation of symbols in the Table 1:

$\begin{array}{ll}\text { INSTIT } & \text { Institutions } \\ \text { INFRA } & \text { Infrastructure } \\ \text { MACRO } & \text { Macroeconomic environment } \\ \text { HEALTH } & \text { Health and primary education } \\ \text { HIGHEDU } & \text { Higher education and training } \\ \text { GOODS } & \text { Goods market efficiency } \\ \text { LABOUR } & \text { Labour market efficiency } \\ \text { FINANCE } & \text { Financial market development } \\ \text { TECHNO } & \text { Technological readiness } \\ \text { MARKET } & \text { Market size } \\ \text { SOPHIS } & \text { Business sophistication } \\ \text { INNOVA } & \text { Innovation }\end{array}$

+ (S) Positive, statistical significant influence of independent variable on dependent variable

- (S) Negative, statistical significant influence of independent variable on dependent variable

NS Influence of independent variable on dependent variable is not statistical significant Influence of Market size on dependent variable

$+(\mathbf{S}) / \mathbf{N S}$ is positive and statistical significant, while influence of Market openness is statistical insignificant

Influence of Market size on dependent variable

- (S)/NS is negative and statistical significant, while influence of Market openness is statistical insignificant

Gichamo (2012) investigated determinants of FDI inflows to the SubSahara African countries. The sample covered 14 developing countries in period from 1986 to 2010 . The author used the panel data analysis and the fixed effects model and based on the obtained results concluded that the market size of these countries positively and statistically significantly affected FDI inflows, while high inflation rate, as an indicator of macroeconomic stability, had a negative, also statistically significant impact. Foreign investors in these countries, in the given period, were not interested in the quality of the infrastructure, as it was found that the impact of this variable on FDI inflows was not statistically significant. 
109 | PILLARS OF COMPETITIVENESS AS FDI DETERMINANTS IN HOST COUNTRIES: A REVIEW OF THE PANEL DATA EMPIRICAL STUDIES

Holland and Pain (1998) examined the determinants of FDI inflows and within the same empirical study, they also analysed the impact of FDI on the economic growth of transition economies. The sample covered 8 Eastern European countries over the short period (1992-1996). Based on the results obtained using the panel data analysis and the fixed effects regression model, it was concluded that labour costs had negative, statistically significant effect on FDI inflows in the countries in the Eastern Europe region over the given period. This result is consistent with the results obtained in similar empirical studies, as labour costs, expressed by wage level in the host country, is one of the traditional determinants of FDI inflows. If an empirical research finds that the impact of this variable is statistically significant, it is always expected to be negative.

Kinoshita and Campos (2002) observed the key factors that a foreign investor considered while making decision on the choice of investment location and found that many potential determinants of FDI inflows were statistically significant for developing countries. The sample covered 25 developing countries, and the research covered the period from 1990 to 1998. Using the panel data analysis and the fixed effects regression model, the authors concluded that the impact of the following independent variables were statistically significant: institutions, infrastructure, skilled labour force, trade liberalization and market size. The quality of infrastructure, the expertise of well-educated workforce, the liberal trade policy and market size of these developing countries, had a positive impact on FDI inflows in the given period. The statistically insignificant impact was determined in the case of inflation and labour costs, which deviates from usual results obtained in similar empirical studies, since these traditional determinants of FDI inflow often appear as statistically significant variables in developing and transition countries, and, almost always, have a negative impact on FDI inflows.

Kudaisi (2014) examined the determinants of FDI inflows in the North African countries from 1980 to 2012 by using the panel data analysis and fixed effects regression model. Based on the obtained results, it was concluded that the impact of infrastructure, inflation and market size on FDI inflows was statistically significant. Namely, quality infrastructure and low inflation rate positively influenced the intensification of FDI inflows in these countries in the given period, while the market size had a negative impact. Foreign investors, who would primarily be interested in these countries as potential investment locations, were often discouraged by modest capacities of national markets and the lack of opportunities to enter international markets. 
Mottaleb (2007) studied the determinants of FDI inflows in developing countries and the impact of FDI on the economic growth of host countries. The sample covered 60 developing countries, i.e. low-income economies and lower middle-income economies. Certain Asian, African and Latin American countries were selected. The results of the panel data analysis and the stochastic effects regression model indicated that the impact of many independent variables on FDI inflows in these countries was not statistically significant. Namely, decision-making processes that led to FDI location choice during 2003, 2004 and 2005 were not affected by the level of corruption, the quality of infrastructure or the time required to start a business and conclude business contracts. FDI inflows were positively affected by size and growth of host countries' markets.

Nishat and Aqeel (2004) examined the determinants of FDI inflows in Pakistan over a very long period (from 1961 to 2002), using the panel data analysis and Error Correction Model. The results of the study showed that the impact of labour costs on FDI inflows was not statistically significant, which is rarely seen in the literature, since most empirical studies identify a negative, statistically significant impact of this independent variable. In this case, 6market size showed a positive, statistically significant impact on FDI inflows. Apart from market size that was very important to foreign investors in Pakistan, reducing the burden on businesses by lowering corporate taxes and tariff rates was also significant. Decision-making process on the choice of Pakistan as an investment location was significantly influenced by the availability of credit to the private sector.

Popovici and Calin (2012), employed panel data analysis and the OLS regression model in order to validate the research hypothesis that national competitiveness is one of the determinants of FDI inflows in host countries. The sample covered 7 countries of the CEE region and EU member states, and the research covered the period from 1996 to 2010. The authors concluded that there was an extremely strong correlation between competitiveness and FDI inflows, and that labour costs, market size and trade openness were the most important determinants of FDI inflows. A sufficiently large and open national market and low labour costs can be very strong drivers of FDI inflows in these countries.

In their next empirical study, Popovici and Calin (2015) changed the structure of independent variables by introducing some pillars of competitiveness in the research, the values of which were taken from the GCR. The authors examined the impact of pillars of competitiveness on FDI inflows in 10 countries of the CEE region and EU member states in 
111 | PILLARS OF COMPETITIVENESS AS FDI DETERMINANTS IN HOST COUNTRIES: A REVIEW OF THE PANEL DATA EMPIRICAL STUDIES

2013 using panel analysis. Pillars of competitiveness (10 selected out of 12) represented independent variables, whereas FDI stocks per capita expressed in euro was a dependent variable. These countries were similar in many respects, especially since they shared a common history of communism and transition. It has been concluded that the impact of macroeconomic stability, higher education and training and financial market development on FDI inflows is not statistically significant in these countries. Competitiveness pillars such as: institutions, infrastructure, goods market efficiency, labour market efficiency, technological readiness, business sophistication and innovation showed positive and statistically significant impact on FDI inflows in these countries in 2013.

Ranjan and Agarwal (2011), researched FDI flows in BRICS countries, in order to determine the key factors that influenced foreign investors to select the aforementioned countries for their investments. A random effect model was employed on the panel data set covering a very long period of research (1975 to 2009). It was concluded that the impact of infrastructure, labour costs, market size and trade openness on FDI inflows was statistically significant. The authors found that inflation rate, as an indicator of macroeconomic stability, and human capital, were not statistically significant variables in this research. Market size had a positive impact on FDI inflows in BRICS countries, which was expected, given the fact that all countries in the sample have large national markets. Also, developed infrastructure in these countries, as well as low labour costs, play an important role in stimulating FDI.

Schneider and Frey (1985) were among the first to analyse the determinants of FDI inflows, and their empirical study from 1985 on economic and political determinants is highly appreciated by scientific circles. The results of the study were later often quoted in the studies of other authors. The sample covered 54 non-European developing countries over three years (1976, 1979 and 1980), and FDI inflow per capita represented the dependent variable. The analysis of panel data and multiple regression led to the results that made authors draw the following conclusions: the impact of political stability, labour skills and market size on FDI inflows in these countries is positive and statistically significant, while the impact of inflation rate and labour costs on FDI inflows is negative and statistically significant as well. Political stability, market size and partly labour skills were stimulating factors for FDI in developing countries in the late 1970s and early 1980s, while high inflation rate and high labour costs discouraged foreign direct investments in these countries. 
Stankov (2017) explored pillars of competitiveness as FDI determinants in the emerging and developing European countries for period 2007 to 2015. In this empirical study, the author addressed the relationship between one dependent variable (FDI inflows expressed in millions of US dollars - Model 1 and FDI inflows as \% of Gross Fixed Capital Formation - Model 2) and several independent variables (12 pillars of competitiveness). Model 1 was deemed more adequate for this study, so the results of the regression analysis of this panel model were used to validate or refute hypotheses and make relevant conclusions. The results from using fixed effects panel estimation showed positive impact of goods market efficiency, as an independent variable, and negative impact of infrastructure, technological readiness and business sophistication on FDI inflows in these countries with a significance level of $1 \%$ and $5 \%$.

Vijayakumar, Sridharan and Sekhara Rao (2010) investigated the determinants of FDI inflows in BRICS countries between 1975 and 2007. Using the panel data analysis and random effects regression model the authors found statistically significant impact of certain variables. The authors concluded that infrastructure and market size had a positive impact on FDI inflows in these countries, while labour cost exerted a negative impact on FDI. The impact of macroeconomic stability (expressed by the rate of inflation) and the impact of trade openness of these countries were not statistically significant.

\section{CONCLUSION}

Based on an overall analysis of various empirical studies whose authors examined indicators of competitiveness as determinants of FDI inflows in host countries, it can be concluded that certain determinants were more intensively studied in comparison to others. One such determinant is market size, which is traditional determinant of FDI inflows. Almost all authors have concluded that the impact of market size on FDI inflows in host countries is positive and statistically significant. The exception is Dhakal, Mixon and Upadhyaya (2007) who found that market size did not significantly affect FDI inflows in 8 European transition economies, and Kudaisi (2014), who concluded that this independent variable had a negative impact on FDI inflows in the case of the 16 countries of North Africa. In addition to market size, labour costs, as an indicator of competitiveness within labour market efficiency was frequently analysed determinant of FDI. Most authors argue that the impact of labour costs on FDI inflows in host countries is negative and statistically significant except for Kinoshita and Campos (2002) and Nishat and Aqeel (2004) who found that there was no statistically significant correlation between SCHOOL OF BUSINESS, 2/2018, 98-116 
113 | PILLARS OF COMPETITIVENESS AS FDI DETERMINANTS IN HOST COUNTRIES: A REVIEW OF THE PANEL DATA EMPIRICAL STUDIES

these variables. Based on the research results, numerous authors concluded that the impact of quality of infrastructure on FDI inflows in host countries was positive and statistically significant. The exceptions are empirical studies of Anyanwu (2011), Gichamo (2012) and Mottaleb (2007), who found that the impact of infrastructure on FDI inflows was statistically insignificant. However, these authors examined infrastructure as determinant of FDI inflows in African countries, and it was mentioned earlier that Africa is distinguished by the fact that certain determinants exert an unusual impact on FDI inflows due to the specificity of the region. While analysing macroeconomic stability as one of the pillars of competitiveness, the authors of empirical studies found very similar results depending on which competitiveness indicators were selected as independent variables (inflation, public debt, foreign exchange reserves or government budget balance). Authors who explored human capital (especially education, skills and expertise) as a determinant of FDI inflows in host countries concluded that this variable exerted a positive, statistically significant impact on dependent variable, or that the impact was not statistically significant (in the analysis of the Chinese regions and BRICS countries). When it comes to other pillars of competitiveness, as independent variables, it is not possible to ascertain such a similarity in the results of different studies.

Encouraged by the belief that there are not enough empirical studies exploring the correlation between national competitiveness and FDI in the literature, especially those studies in which econometric methodology is applied in the field of panel data regression model, the authors of this paper have carried out a detailed overview of the existing literature on the subject and contributed to establishing a scientific base that will represent a reliable basis for future empirical research. In addition, the results of this study can have significant practical implications for policymakers, especially for those policies that promote foreign investment.

\section{REFERENCES}

Amar, M., B. \& Hamdi, M., T. (2012). Global Competitiveness and Economic Growth: Empirical Verification for African Countries. International Journal of Economics and Finance, 4(6).

Anastassopoulos, G. (2007). Countries' International Competitiveness and FDI: an empirical analysis of selected EU Member-Countries and Regions. Journal of Economics and Business, 10(1), 35-52.

Anyanwu, J., C. (2011). Determinants of foreign direct investment inflows to Africa, 1980-2007. African Development Bank Group. 
Baltagi, B., H. (2005). Econometric Analysis of Panel Data. England: John Wiley \& Sons

Bevan, A., \& Estrin, S. (2004). The determinants of foreign direct investment into European transition economies. Journal of Comparative Economics, 32(4), 775-787.

Bevan, A., Estrin, S., (2000). The determinants of foreign direct investment in transition economies. CEPR discussion paper, No. 2638 .

Cheng, L., K., \& Kwan, Y., K. (2000). What are the determinants of the location of foreign direct investment? The Chinese experience. Journal of International Economics, 51(2), 379-400.

Criste, A., Mosneanu, E., A., \& Glod, A., G. (2008). O abordare a conceptului de competitivitate naţională. Studii Financiare (Financial Studies), 12(4), 51-59.

Dhakal, D., Mixon Jr, F., \& Upadhyaya, K. (2007). Foreign direct investment and transition economies: empirical evidence from a panel data estimator. Economics Bulletin, 6(33), 1-9.

Dragutinović Mitrović, R. (2002). Analiza panel serija. Beograd: Zadužbina Andrejević.

Gichamo, T. Z. (2012). Determinants of Foreign Direct Investment Inflows to Sub-Saharan Africa: a panel data analysis. Södertörns University Department of Economics Master Programme.

Gujarati, D. (2004). Basic Econometrics. United States Military Academy, West Point.

Gujarati, D., N., \& Porter, D. (2009). Basic Econometrics. Mc Graw-Hill International Edition.

Holland, D., \& Pain, N. (1998). The determinants and impact of foreign direct investment in the transition economies: a panel data analysis. In Convergence or Divergence: Aspirations and Reality in Central and Eastern Europe and Russia (Proceedings from 4th Annual conference). Centre for Research into East European Business, University of Buckingham.

Kinoshita, Y., \& Campos, N., F. (2002). The location determinants of foreign direct investment in transition economies. University of Michigan William Davidson Institute and CERP. 
115 | PILLARS OF COMPETITIVENESS AS FDI DETERMINANTS IN HOST COUNTRIES: A REVIEW OF THE PANEL DATA EMPIRICAL STUDIES

Kudaisi, B., V. (2014). An empirical determination of foreign direct investment in West Africa countries: a panel data analysis. International Journal of Development and Economic Sustainability, 2(2), 19-36.

Matyas, L., \& Sevestre, P. (1996). The econometrics of panel data: a handbook of the theory with applications. Kluwer Academic Publisher.

Mottaleb, K., A. (2007). Determinants of foreign direct investment and its impact on economic growth in developing countries. MPRA Munich Personal RePEc Archive.

Nishat, M., \& Aqeel, A. (2004). The determinants of foreign direct investment in Pakistan. The Pakistan Development Review, 651664.

Popovici, O., C., \& Călin, A., C. (2012a). Competitiveness as Determinant of Foreign Direct Investments in Central and Eastern European Countries. Revista Economica, 1/2012, 658-666.

Popovici, O., C., \& Calin, A., C. (2015). The Effects of Enhancing Competitiveness on FDI Inflows in CEE Countries. European Journal of Interdisciplinary Studies, 7(1), 55.

Ranjan, V. \& Agrawal, G. (2011). FDI Inflow Determinants in BRIC Countries: A Panel Data Analysis. International Business Research, 4(4), 255.

Schneider, F., \& Frey, B. (1985). Economic and political determinants of foreign direct investment. World Development, 13(2), 161-175.

Stankov, B. (2017). Panel analysis of foreign direct investments and competitiveness in emerging and developing European countries (Ph.D. Thesis). Novi Sad, Republic of Serbia: Faculty of economics and engineering management in Novi Sad, University Business Academy.

Stankov, B., Markov, J., \& Marjanski Lazić, S. (2014). Pillars of competitiveness of former Yugoslav republics. In Proceeding from 4th International Symposium Engeneering Management and Competiteveness - EMC (378-384). Zrenjanin: Technical Faculty "Mihajlo Pupin" Zrenjanin.

Ungureanu, E., \& Burcea, F. C. (2014). Competitiveness - key for economic development. Study case among the Central and Eastern economies in EU. In Proceeding from International 
Biljana Stankov, Jelena Damnjanović, Milijana Roganović| 116

multidisciplinary symposium „Universitaria SIMPRO 2014“. Romania: Universitatea din Petrosani.

Vijayakumar, N., Sridharan, P., \& Sekhara Rao, K., C. (2010). Determinants of FDI in BRICS Countries: A panel analysis. International Journal of Business Science \& Applied Management, 5(3).

Delivered: 24.12.2018. Accepted: 19.03.2019. 